\title{
Mast Cells and Basophils: A Potential Link in Promoting Angiogenesis during Allergic Inflammation
}

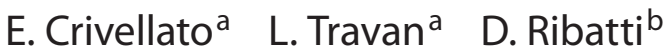 \\ aDivision of Anatomy, Department of Medical and Morphological Research, University of Udine Medical School,

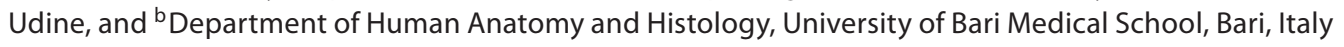

\section{Key Words}

Allergic inflammation · Angiogenesis · Basophils · Mast cells

\begin{abstract}
Mast cells and basophils are granulated metachromatic cells which possess complex and partially overlapping roles in acquired and innate immunity, including both effector and regulatory activities. Mast cells and basophils cooperate in exacerbating and/or modulating inflammation as well as in mediating subsequent tissue repair. Mast cells release a series of potent proangiogenic molecules during inflammation that stimulate vessel sprouting and new vessel formation. Recent data suggest that basophils may also play a role in inflammation-related angiogenesis, principally but not exclusively through the expression of several forms of vascular endothelial growth factors and their receptors. This review focuses on the potential cooperative link between mast cells and basophils in promoting angiogenesis during allergic inflammation. We discuss the multifaceted roles of mast cells and basophils in inflammatory mechanisms of allergic diseases and whether these cells can be both source and target of proangiogenic mediators.
\end{abstract}

Copyright ๑ 2009 S. Karger AG, Basel

\section{Introduction}

Mast cells and basophils represent distinct hematopoietic lineages that can express complementary or overlapping functions in the context of acute and chronic immunoglobulin E (IgE)-associated allergic responses $[1,2]$. Recent work shows that mast cells and basophils also play a critical role in innate immunity to parasite and bacterial infection [3]. In addition, both cells can be activated by viral proteins $[4,5]$. Mast cells have increasingly been implicated in the regulation and modulation of adaptive immune responses, in autoimmunity as well as in the expression of peripheral tolerance $[2,6]$. Besides, mast cells contribute to non-immunological functions, such as tissue repair and remodelling, as well as tissue angiogenesis [7]. This review will discuss recent advances in understanding the potential cooperative link between mast cells and basophils, which may promote angiogenesis in the course of allergic inflammation.

\section{Natural History of Mast Cells and Basophils}

First described by the German pathologist Paul Ehrlich $[8,9]$, mast cells and basophils are granulated metachromatic cells, which share some phenotypic and functional properties but differ in important aspects of natural

\section{KARGER}

Fax +4161306 1234 E-Mail karger@karger.ch www.karger.com
Correspondence to: Prof. Enrico Crivellato

Division of Anatomy, Department of Medical and Morphological Research

University of Udine Medical School, Piazzale Kolbe 3

IT-33100 Udine (Italy)

Tel. +39 0432494 221, Fax +390432 494 201, E-Mail enrico.crivellato@uniud.it 
history, mediator content, and function. Metachromatic staining of cytoplasmic granules primarily reflects their content of proteoglycans such as chondroitin sulfates (in basophils and mast cells) and heparin (in mast cells exclusively) [10]. Mast cells are tissue-resident cells originating from CD34+ hematopoietic stem cells and migrating into almost all of the major organs as immature committed progenitors [11]. Here, they complete their differentiation under the influence of tissue microenvironmental factors, in particular the stem cell factor, the ligand for the c-kit tyrosine kinase III growth factor receptor (secreted by fibroblasts, stromal cells and endothelial cells), which critically regulate many aspects of mast cell development and survival [12]. Mature mast cells can be very long lived and can retain their ability to proliferate under certain conditions. Mast cells are particularly found in association with connective tissue structures such as blood vessels, lymphatic vessels and nerves, and in proximity to surfaces that interface the external environment such as those of the respiratory and gastrointestinal tracts and the skin. This selective accumulation at tissue sites where foreign material attempts to invade the host suggests that these cells are among the first cells to initiate defense mechanisms. In contrast to mast cells, basophils are circulating granulocytes that typically mature in the bone marrow, circulate in the blood as mature cells and can be recruited to sites of immunological or inflammatory responses but are not found in normal tissues [13]. They also arise from $\mathrm{CD} 34+$ hematopoietic progenitors and, under physiological conditions, have a short life span of several days. Unlike mast cells, they do not proliferate once they mature. As basophils lack c-kit, they do not respond to stem cell factor. By contrast, their differentiation is crucially driven by interleukin (IL)-3, which promotes the production and survival of human basophils in vitro and can induce basophilia in vivo [14].

\section{Mast Cell and Basophil Mediators}

Following appropriate stimulation, mast cells and basophils release secretory products by anaphylactic degranulation ('compound exocytosis') or piecemeal degranulation, a slow, particular and possibly selective mode of cell secretion mediated by vesicle transport of granule-stored material [10]. Mediators are either preformed and granule associated or are synthesized de novo. Major mediators stored preformed in mast cell granules are histamine, heparin, serine proteases such as tryptase and chymase, cathepsin G, peroxidase, many acidic hydrolases, carboxypeptidases and antimicrobial peptides such as cathelicidins [15]. Basophil granules contain less amounts of histamine, lack heparin but contain proteoglycans like chondroitin sulfates and CharcotLeyden crystal protein. Mouse but not human basophil granules express TSLP (thymic stromal lymphopoietin) [16]. A human basophil-specific protein, basogranulin, is released upon cell degranulation [17]. In some allergic patients, circulating basophils may contain tryptase, chymase and carboxypeptidase A, and express the c-kit receptor, which is normally absent on the surface of basophils, suggesting that these cells may modulate their phenotype [18]. Proinflammatory lipid mediators de novo synthesized and released by mast cells include prostaglandins $\left(\mathrm{PGE}_{2}\right.$ and $\mathrm{PGD}_{2}$ ), cysteinyl leukotrienes $\left(\mathrm{LTB}_{4}\right.$ and $\left.\mathrm{LTC}_{4}\right)$ and platelet-activating factor [15]. By contrast, $\mathrm{LTC}_{4}$ and platelet-activating factor are the only identified lipid mediators released by basophils [16]. Both mast cells and basophils synthesize and release an array of growth factors, cytokines and chemokines involved in inflammation, immunity, hematopoiesis, tissue remodelling and other biological functions. Human and mouse mast cells secrete tumor necrosis factor (TNF)- $\alpha$, transforming growth factor (TGF)- $\beta$, fibroblast growth factor (FGF)-2, vascular endothelial growth factor (VEGF), granulocyte macrophage-colony stimulating factor (GM$\mathrm{CSF}$ ), nerve growth factor (NGF), platelet-derived growth factor, interferon- $\alpha,-\beta$ and $-\gamma$, many ILs (IL- $1 \alpha$, IL- $1 \beta$, IL-3, IL-4, IL-5, IL-6, IL-8, IL-9, IL-10, IL-11, IL-12, IL-13, IL-15, IL-16, IL-18 and IL-25), and several C-C and CXC chemokines, including monocyte chemotactic protein (MCP)-1 (CCL2) and macrophage inflammatory protein$1 \alpha$ (CCL3). IL-8 (CXCL-8) has chemokine functions as well [15]. By contrast, basophils secrete a restricted array of products such as VEGF, IL-4, IL-6 and IL-13 [19]. These data suggest that mast cells and basophils can participate in intricate paracrine and autocrine networks that may contribute to leukocyte recruitment, stromal and tissue cell activation, modulation of immune functions, tissue remodelling and angiogenesis [20].

\section{Immunological Functions of Mast Cells and Basophils}

Both mast cells and basophils express the tetrameric $\alpha \beta \gamma_{2}$ form of the high-affinity receptor FceRI for IgE on their surface and both kinds of cells are crucial effectors in T-helper 2 (Th2) cell-dependent, IgE-associated allergic disorders and immune responses to parasites [21-23]. 
The cross-linking of IgE bound to the high-affinity receptor FceRI with bivalent or multivalent antigen results in the aggregation of FceRI on the surface of these cells, which is sufficient for initiating downstream signal transduction events that activate cell degranulation as well as de novo synthesis and secretion of lipid mediators and cytokines [24]. Binding of IgE to FceRI not only regulates mast cell and basophil functions but might directly or indirectly influence cellular survival and resistance to apoptosis [25]. In addition, both mast cells and basophils can be activated by IgG-mediated mechanisms $[26,27]$ as well as $\mathrm{G}$ protein-coupled receptor and Toll-like receptor activation mechanisms $[3,28,29]$. Mediators released by mast cells and basophils have effector, immunoregulatory or autocrine effects that profoundly influence the orchestration of allergic inflammation. Beyond influencing immune responses via the secretion of cytokines, in vitro experiments suggest that human mast cells and basophils can function as antigen-presenting cells and/or represent sources of costimulatory activity (e.g. by expressing CD40 or its ligand) [30, 31].

Mast cells and basophils also participate in host defense against bacteria, viruses, fungi and parasites [32]. Besides releasing biologically potent mediators, mast cells express a wide spectrum of surface receptors for cytokines, chemokines and bacterial products [33]. This enables mast cells to perform crucial functions in the context of either acquired or innate immune responses. It is now clear that mast cells are involved in a variety of pathological settings, including autoimmunity [6]. Interestingly, mast cells express either beneficial or detrimental effects in a number of physiological and pathological processes. Murine mast cells, for instance, provide a crucial life-saving role in experimental bacterial infections. In genetically mast cell-deficient $\mathrm{W} / \mathrm{W}^{\mathrm{V}}$ mice, mast cells exert a fundamental protective role in a model of acute septic peritonitis following cecum ligation and puncture, and in a model of enterobacteria inocula $[34,35]$. This protective effect is mainly due to the release of TNF- $\alpha$, but other mast cell-derived products, such as cathelicidins and chymase, may have direct bactericidal activity or degrade toxic peptides [3]. In a recent study, mast cells reduced neurotensin-related mortality in a mouse model of sepsis [36]. Thus, mast cells may behave as vital sentinels that orchestrate potent inflammatory reactions against different microorganisms, linking innate immunity with the adaptive immune system. On the other hand, they play a critical role in initiating or aggravating disease in models of rheumatoid arthritis, multiple sclerosis, bullous pemphigoid and atherosclerosis in mice
[37]. Mast cells and basophils may possess similar or overlapping functions in immunity against parasites. Parasite infections are often associated with increased levels of circulating basophils, increased serum levels of $\mathrm{IgE}$, and increased numbers of mast cells and/or basophils in the affected tissues both in man and mice [22]. Human mast cells and basophils may be activated by bacterial superantigens, such as protein L of Pneumococcus magnus, protein A of Staphylococcus aureus, the Hp(220)-derived peptide from Helicobacter pylori and viral antigens, and HIV glycoprotein 120 (gp120), which interact with distinct regions of IgE, inducing mediator release from these cells $[4,5,38]$.

\section{From Acute Allergic Reaction to Chronic Allergic Inflammation}

Mast cells and basophils are key effector cells in initiating and/or amplifying IgE-dependent inflammatory reactions $[15,39]$. In addition, they also express immunoregulatory functions in the same settings $[1,2,20,40]$. Both mast cells and basophils are activated during IgE-associated anaphylaxis. Anaphylaxis is an acute-phase, potentially fatal systemic allergic reaction that can be triggered by immunological or non-immunological mechanisms [41]. IgE plays a crucial role in the immediate hypersensitivity response through binding with the highaffinity receptor FceRI, but other IgE-independent mechanisms, such as $\mathrm{G}$ protein-coupled receptor and Toll-like receptor activation processes, may intervene $[42,43]$. Activated mast cells and basophils release Th2 cytokines (IL-4, IL-5, IL-9 and IL-13) that polarize the immune reaction, and produce various bioactive chemical mediators, such as histamine and lipid metabolites, that provide vasoactive, chemotactic and immunoregulatory functions $[44,45]$. Remarkably, during inflammation, both human and mouse basophils release considerable amounts of IL-4 very rapidly, thus they may have a critical impact on the outcome of a primary infection $[13,20,46]$.

In addition to their roles in classic acute IgE-associated immediate hypersensitivity responses, several lines of evidence indicate that mast cells and basophils can also contribute to late-phase and chronic allergic reactions [39, 47-49]. Mast cells have been shown to change their degranulation pattern from acute to chronic allergic responses [50]. Anaphylactic degranulation is triggered by IgE-dependent and neuropeptide activation mainly during the early phase of allergic reactions [39]. Differential release without degranulation is activated by mediators 
such as IL-1 (in humans), stem cell factor (in mice), lipopolysaccharide (in rats) and corticotropin-releasing hormone (in humans), and classically occurs during chronic inflammatory diseases [50,51]. Many clinical symptoms of IgE-dependent late-phase reactions, in the respiratory and gastrointestinal tract and in the skin, reflect the actions of leukocytes recruited to these sites by mast cells and basophils. Cytokines (TNF- $\alpha$, IL- 6 and IL-8) and neutral proteases, as well as histamine and lipid mediators, may contribute to mast cell- and basophil-dependent leukocyte recruitment - in particular eosinophil recruitment - in such settings [52]. Leukocytes, in turn, exacerbate the inflammatory reaction by providing additional proinflammatory mediators and cytokines ('mast cell-leukocyte cytokine cascade'). In the course of chronic allergic inflammation in humans, the cellular infiltrates present in the skin, upper airways and lungs are similar in composition and characterized by prominent eosinophils and T cells, with smaller numbers of monocytes, macrophages and mast cells [39, 53-55]. Basophils are also recruited to late-phase reaction sites such as the skin, nose and lower airways in humans [56]. Certain mast cell cytokines, such as TNF- $\alpha$, VEGF, FGF-2 and TGF- $\beta$, contribute to chronic allergic inflammation through effects on fibroblasts, vascular endothelial cells and other cells resident at the sites of these reactions [39]. Persistent chronic allergic inflammation can result in remodelling of the affected tissues, and these structural changes are often associated with activation of the angiogenic process [47]. Indeed, airway tissues from patients with asthma characteristically show blood vessel proliferation in the mucosa and submucosa besides infiltration of the submucosa and epithelium by mast cells, basophils, $\mathrm{T}$ cells and eosinophils, epithelial thickening, smooth muscle cell hypertrophy, mucous gland hyperplasia, and collagen and tenascin deposition beneath the epithelial basement membrane [47].

\section{Inflammation and Angiogenesis}

Angiogenesis, i.e. the formation of new blood vessels from the preexisting vasculature, is a multistep complex phenomenon crucial for numerous inflammatory and immune disorders, including allergic diseases [57]. In 1960, Dunnil [58] demonstrated for the first time that asthmatic subjects who succumb acute attacks have an enlarged capillary bed in the airway wall. Later on, increased vascularity in the airways has been recognized not only in patients with severe asthma, but also in those with mild disease $[59,60]$. The major structural and functional changes in the airway microcirculation include the proliferation of new vessels, increased vascular areas of medium and small airways, increased blood flow and microvascular permeability, and edema formation in the airway wall $[61,62]$.

Cytokines of the CXC family play a pivotal role in the control of inflammation and angiogenesis since their specific receptors do not differ from those expressed on leukocytes and endothelial cells [63]. Thus, CXC chemokines are not only responsible for leukocyte recruitment to inflamed tissues, they also regulate the inflammatory reaction leading to angiogenesis, tissue repair and new tissue generation [64-66]. Recent evidence indicates that endothelial cells express specific CXC receptors (CXCR), such as CXCR1, CXCR2, CXCR3 and CXCR4, which induce endothelial cell chemotaxis and form blood vessels [67].

Human mast cells and basophils are endowed with a wide set of chemokine receptors. Basophils constitutively express CCR1, CCR2, CCR3, CXCR1, CXCR3 and CXCR4 $[20,45]$. CCR3 is highly expressed on human basophils and can be activated by eotaxin (CCL11), RANTES (CCL5), MCP-3 (CCL7) and MCP-4 (CCL13) [68]. In contrast to human basophils, mouse basophils do not express CCR3. Interestingly, CCR 3 is also expressed by about $25 \%$ of lung mast cells in subjects with bronchial asthma [69]. Upon IgE overproduction, mouse basophils release CCL22, a potent chemoattractant for Th2 cells which has been implicated in Th2-predominant allergic inflammation [70].

Mast cells and basophils are a major source of several angiogenic factors and display their receptor counterparts on their membrane, thus influencing angiogenesis during allergic inflammation (fig. 1). Both mast cells and basophils synthesize and release VEGF, the most potent proangiogenic mediator known so far [71, 72]. Murine mast cells lacking JunB, a member of the AP-1 transcription factor family regulating IgE-mediated mast cell degranulation, severely impair in vitro angiogenesis due to inhibition of VEGF secretion [73]. Human mast cells, however, are a potent source of VEGF in the absence of degranulation through activation of the $\mathrm{EP}_{2}$ receptor by $\mathrm{PGE}_{2}$ [74]. Selective release of VEGF by human mast cells is regulated by corticotropin-releasing hormone [75]. VEGF is also produced by human basophils [72]. Basophils express mRNA for various members of the VEGF family. Peripheral blood and basophils infiltrating sites of chronic inflammation, e.g. nasal polyps, contain VEGF-A in their secretory granules. In addition, human basophils express the tyrosine kinase VEGF-A receptor VEGFR-2/KDR, and neurophilin-1, which acts as a core- 
Fig. 1. Mast cells and basophils are a major source of several angiogenic factors that promote new vessel formation during allergic inflammation. MMP-9 = Matrix metalloproteinase-9.

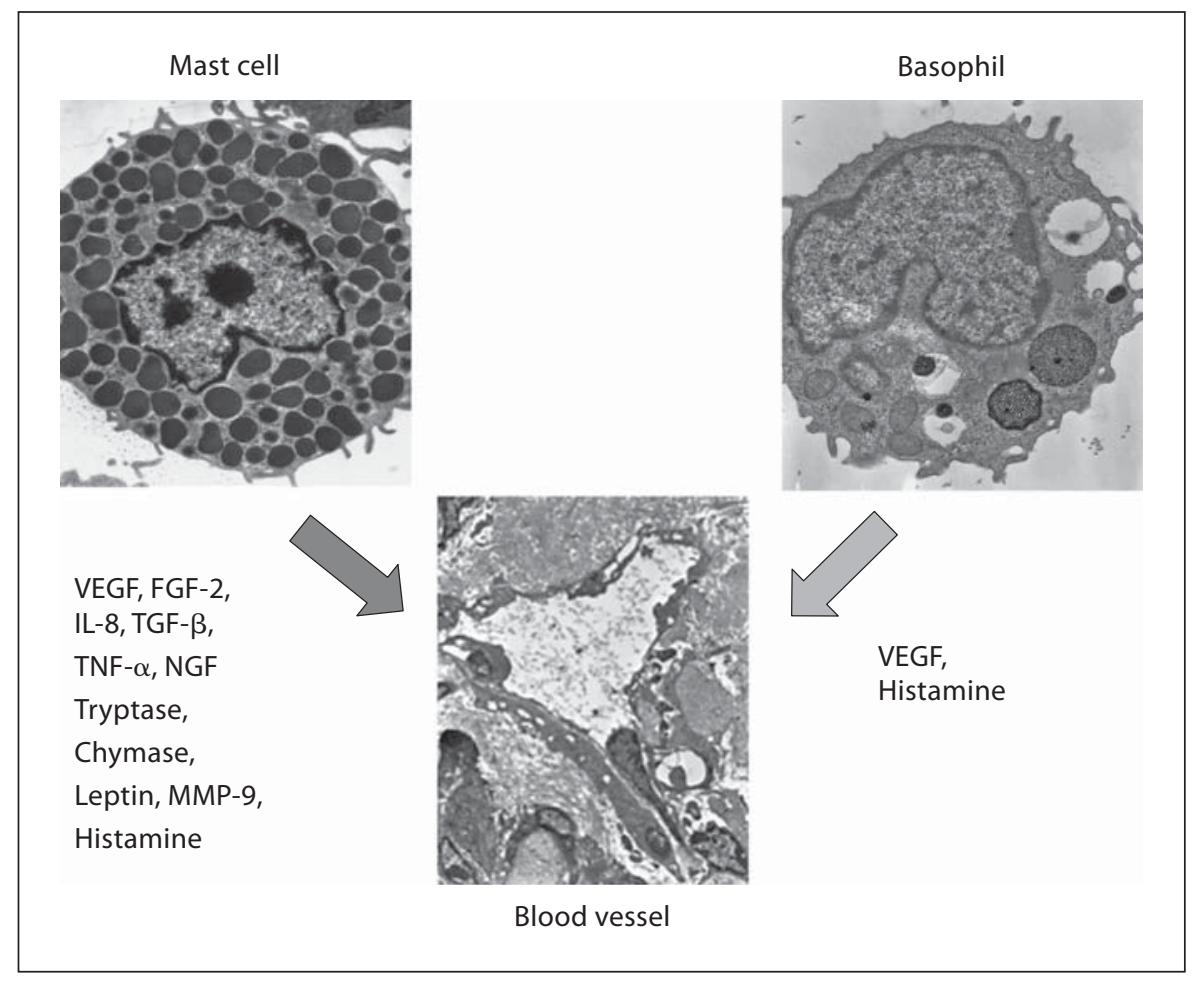

ceptor for VEGFR-2/KDR and enhances VEGFR-2-induced responses. Remarkably, VEGF-A also functions as basophil chemoattractant providing a novel autocrine loop for basophil self-recruitment. Both mast cells and basophils release histamine, which displays angiogenic activity in several in vitro and in vivo settings [76]. Mast cells synthesize and release other potent angiogenic cytokines, e.g. FGF-2, the serine proteases tryptase and chymase, IL- 8 , TGF- $\beta$, TNF- $\alpha$ and NGF [50]. Recently, mast cells from human uterine leiomyomas have been found to contain leptin, a 167-amino-acid residue peptide mainly secreted by adipocytes which, besides its involvement in obesity development, expresses angiogenic activity [77]. In addition, human skin, lung and synovial mast cells contain matrix metalloproteinase- 9 , which degrades the extracellular matrix, thus releasing angiogenic factors bound to the extracellular matrix [78].

\section{Mast Cell and Basophil Cross-Talk in Inflammatory Angiogenesis}

Mast cells and basophils also participate in inflammation, along with other blood-borne and tissue-resident cells involved in different allergic reactions. These cells cooperate in the exacerbation and/or modulation of inflammation as well as in mediating tissue remodelling and angiogenesis [79]. Many mediators and receptors are involved in such paracrine and autocrine signaling (fig. 2). Human basophils express the seven-transmembrane receptor CRTH2 (chemoattractant receptor-homologous molecule expressed on Th2 cells) whose activation by mast cell-released $\mathrm{PGD}_{2}$ induces basophil chemotaxis [80]. Basophil-released histamine, in turn, may potentiate mast cell chemotaxis at sites of inflammation via interaction with the $\mathrm{H}_{4}$ receptor [81]. Interestingly, mast cell- and basophil-released histamine downregulates basophil responses by inhibiting the release of mediators from human basophils via the $\mathrm{H}_{2}$ receptor [82]. Cysteinyl leukotrienes produced by immunologically activated mast cells and basophils exert a variety of responses by activating the receptors CysLTR 1 and CysLTR 2 , which are expressed, among other cells, by mast cells and basophils themselves $[83,84]$. IL- 4 and $\mathrm{LTC}_{4}$, secreted by mast cells and basophils, upregulate the expression of CysLTR and stimulate $\mathrm{LTC}_{4}$ and cytokine production by human mast cells. MCP-1 (CCL2) secreted by mast cells may induce stimulation of histamine and leukotriene release from human basophils and mast cells themselves [85]. Both human mast cells and basophils release VEGF, 


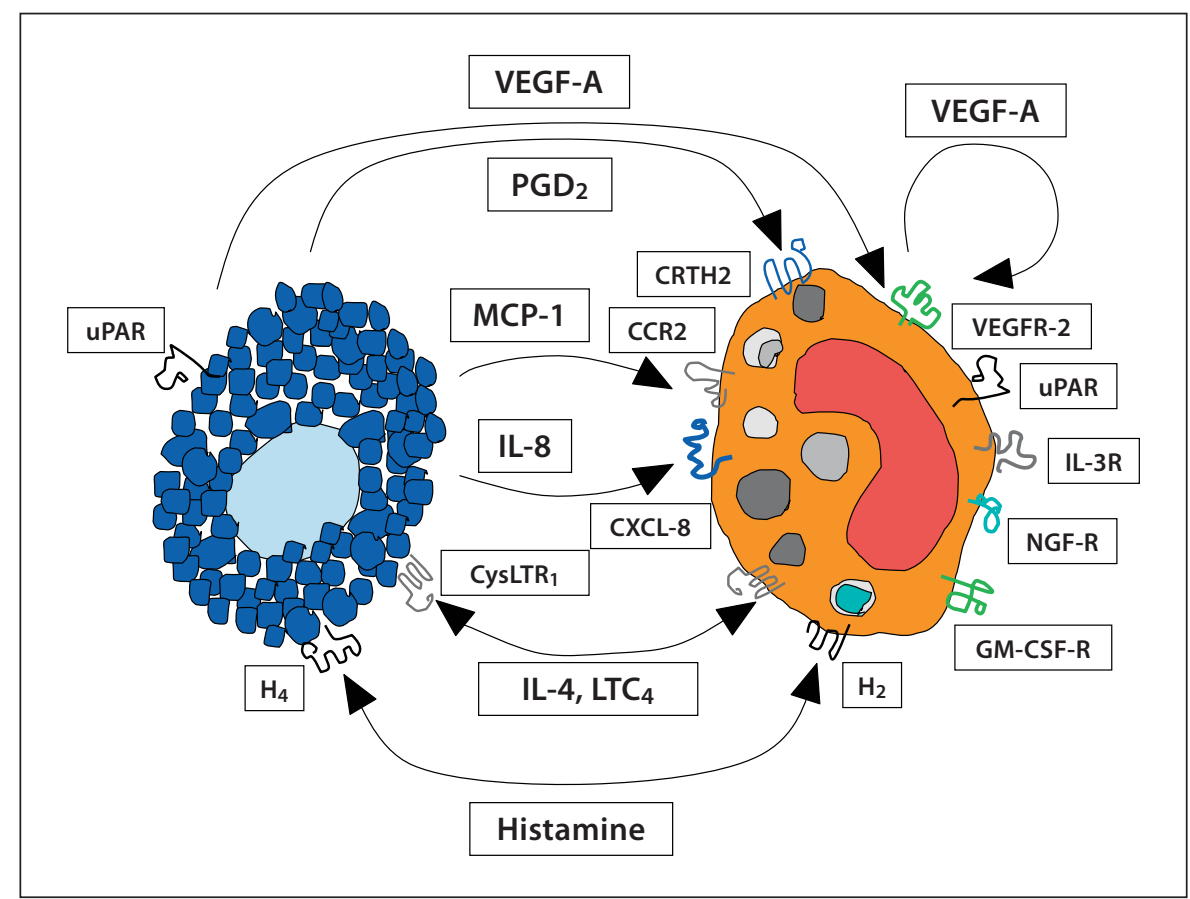

Fig. 2. Mast cell and basophil cross-talk during inflammatory angiogenesis. $\mathrm{PGD}_{2}$ released by mast cells activates basophil chemotaxis through CRTH2 receptor. During inflammation, macrophage inflammatory protein-1 $\alpha$ (CCL3) and IL-8 (CXCL-8) secreted by mast cells attract basophils via CCR1, CCR5 and CXCL-8 receptors located on the basophil surface. Basophils, in turn, secrete IL-4 and $\mathrm{LTC}_{4}$, which upregulate the expression of CysLTR $_{1}$ and stimulate LTC $_{4}$ and cytokine production by mast cells. In addition, histamine released by basophils potentiates mast cell recruitment through $\mathrm{H}_{4}$ receptors. Conversely, mast

which is the most potent inducer of endothelial cell proliferation, migration, survival and tube formation [71, 72]. VEGF also presents proinflammatory cy tokine functions and, remarkably, acts on basophils as chemoattractant [72]. So, mast cell-released VEGF concurs with basophil recruitment at inflammatory sites. Interestingly, human basophils express a number of receptors for growth factors released by mast cells, e.g. IL-2R, IL-3R, IL-4R, IL-5R, GM-CSF-R, NGF-R and IL-8 (CXCL-8) [86]. Cytokines such as IL-3, IL-5, IL-8 and GM-CSF have been associated with the tissue influx and subsequent activation of human basophils [13]. In addition, both human mast cells and basophils express the high-affinity urokinase plasminogen activator (uPA) receptor (uPAR) [87, 88], a potent chemoattractant for both kinds of cells, and, remarkably, uPA and uPAR are involved in tissue remodelling and vessel sprouting $[88,89]$. cell-released histamine downregulates basophil activation via $\mathrm{H}_{2}$ receptors. Both cell types release the potent proangiogenic cytokine VEGF-A, which is also chemotactic for basophils. MCP-1 (CCL2) secreted by mast cells may stimulate histamine and leukotriene release from basophils through the CCR2 receptor. In addition, basophils express on their surface a number of receptors for growth factors released by mast cells, such as IL-3R, GM-CSFR or NGF-R, which may play a still undetermined role in the modulation of basophil function.

\section{Concluding Remarks}

Human mast cells and basophils are conventionally considered primary effector cells in different allergic conditions such as bronchial asthma. We feel that it is too soon to conclude whether and to what extent mast cells and basophils are involved in tissue remodelling associated with allergic inflammation. However, several lines of evidence suggest that mast cells and basophils may contribute to this process. These cells produce several mediators and express surface receptors that provide the basis for complex paracrine and autocrine cross-talking networks. In addition, mast cell- and basophil-derived secretory products express a number of in vitro or in vivo effects that are consistent with the hypothesis that both cells can cooperate in promoting tissue neovascularization during allergic inflammation. Thus, these cells can be both source and target for proangiogenic mediators. 
Angiogenesis is a critical step in the perpetuation of allergic inflammation via the release of VEGF and other angiogenic mediators. Thus, strategies directed to downregulate VEGF production might be of benefit in the treatment of allergic diseases.

\section{Acknowledgment}

This study has been supported by local funds from the Ministry of Education, University and Research (MIUR) to the Division of Anatomy, Department of Medical and Morphological Research, University of Udine.

\section{References}

-1 Gribaldeston MA, Metz M, Yu M, Tsai M, Galli SJ: Effector and potential immunoregulatory roles of mast cells in IgE-associated acquired immune responses. Curr Opin Immunol 2006;18:751-760.

$\checkmark 2$ Galli SJ, Grimbaldeston M, Tsai M: Immunomodulatory mast cells: negative, as well as positive, regulators of immunity. Nat Rev Immunol 2008;8:478-486.

$\checkmark 3$ Metz M, Siebenhaar F, Maurer M: Mast cell functions in the innate skin immune system. Immunobiology 2008;213:251-260.

4 Patella V, Giuliano A, Bouvet JP, Marone G: Endogenous superallergen protein $\mathrm{Fv}$ induces IL-4 secretion from human Fce $\mathrm{R}^{+}$cells through interaction with the $\mathrm{V}_{\mathrm{H}} 3$ region of IgE. J Immunol 1998;161:5647-5655.

5 Patella V, Florio G, Petraroli A, Marone G: HIV-1 gp120 induces IL-4 and IL-13 release from $\mathrm{Fc} \varepsilon \mathrm{R}^{+}$cells through interaction with the $\mathrm{V}_{\mathrm{H}} 3$ region of IgE. J Immunol 2000;164: 589-595.

6 Sayed BA, Christy A, Quirion MR, Brown MA: The master switch: the role of mast cells in autoimmunity and tolerance. Annu Rev Immunol 2008;26:705-739.

7 Galli SJ, Tsai M: Mast cells: versatile regulators of inflammation, tissue remodeling, host defense and homeostasis. J Dermatol Sci 2008;49:7-19.

8 Ehrlich P: Beiträge zur Theorie und Praxis der histologischen Färbung; thesis, Leipzig University, 1878.

9 Ehrlich P: Beiträge zur Kenntnis der granulierten Bindgewebszellen und der eosinophilen Leukozyten. Arch Anat Physiol 1879; 3:166-169.

10 Dvorak AM: Ultrastructural studies of human basophils and mast cells. J Histochem Cytochem 2005;53:1043-1070.

-11 Okayama Y, Kawakami T: Development, migration and survival of mast cells. Immunol Res 2006;34:97-115.

12 Ashman LK: The biology of stem-cell factor and its receptor c-kit. Int J Biochem Cell Biol 1999;31:1037-1051.

-13 Arock M, Schneider E, Boissan M, Tricottet V, Dy M: Differentiation of human basophils: an overview of recent advances and pending questions. J Leukoc Biol 2002;71: 557-564.
14 Valent P, Schmidt G, Besemer J, Mayer P, Zenke G, Liehl E, Hinterberger W, Lechner $\mathrm{K}$, Maurer D, Bettelheim P: Interleukin-3 is a differentiation factor for human basophils. Blood 1989;73:1763-1769.

15 Galli SJ, Kalesnikoff J, Grimbaldeston MA, Piliponsky AM, Williams CMM, Tsai M Mast cells as 'tunable' effector and immunoregulatory cells: recent advances. Annu Rev Immunol 2005;23:749-786.

16 Karasuyama H, Mukai K, Tsujimura Y, Obata K: Newly discovered roles for basophils: a neglected minority gains new respect. Nat Rev Immunol 2009;9:9-13.

17 Mochizuki A, McEuen AR, Buckley MG Walls AF: The release of basogranulin in response to IgE-dependent and IgE-independent stimuli: validity of basogranulin measurement as an indicator of basophil activation. J Allergy Clin Immunol 2003;112: 102-108.

-18 Li L, Li Y, Reddel SW, Cherrian M, Friend DS, Stevens RL, Krilis SA: Identification of basophilic cells that express mast cell granule proteases in the peripheral blood of asthma, allergy and drug-reactive patients. J Immunol 1998;161:5079-5086.

19 Sullivan BM, Locksley RM: Basophils: a nonredundant contributor to host immunity. Immunity 2009;30:12-20.

20 Gibbs BF: Human basophils as effectors and immunomodulators of allergic inflammation and innate immunity. Clin Exp Med 2005;5:43-49.

21 Gould HJ, Sutton BJ, Beavil AJ, Beavil RL, McCloskey N, Coker HA, Fear D, Smurthwaite L: The biology of IgE and the basis of allergic disease. Annu Rev Immunol 2003; 21:579-628.

-22 Prussin C, Metcalfe DD: IgE, mast cells, basophils, and eosinophils. J Allergy Clin Immunol 2003;111:S486-S494.

23 Min B, Prout M, Hu-Li J, Zhu J, Jankovic D, Morgan ES, Urban JF Jr, Dvorak AM, Finkelman FD, LeGros G, Paul WE: Basophils produce IL- 4 and accumulate in tissues after infection with a Th2-inducing parasite. J Exp Med 2004;200:507-517.

24 MacGlashan D: IgE receptor and signal transduction in mast cells and basophils. Curr Opin Immunol 2008;20:1-7.

-25 Kawakami T, Galli SJ: Regulation of mast cell and basophil function and survival by IgE. Nat Rev Immunol 2002;2:773-786.
26 Malbec O, Daëron M: The mast cell IgG receptors and their roles in tissue inflammation. Immunol Rev 2007;217:206-221.

27 Tsujimura Y, Obata K, Mukai K, Shindou H, Yoshida M, Nishikado H, Kawano Y, Minegishi Y, Shimizu T, Karasuyama H: Basophils play a pivotal role in immunoglobulin-Gmediated but not immunoglobulin-E-mediated systemic anaphylaxis. Immunity 2008; 28:581-589

28 Komiya A, Nagase H, Okugawa S, et al: Expression and function of Toll-like receptors in human basophils. Int Arch Allergy Immunol 2006;140(suppl 1):23-27.

29 Bachelet I, Levi-Schaffer F: Mast cells as effector cells: a costimulating question. Trends Immunol 2007;28:360-365.

30 Gauchat JF, Henchoz S, Mazzei G, Aubry JP, Brunner $\mathrm{T}$, Blasey $\mathrm{H}$, Life $\mathrm{P}$, Talabot $\mathrm{D}$, Flores-Romo L, Thompson J, Kishi K, Butterfield J, Dahinden C, Bonnefoy JY: Induction of human IgE synthesis in B cells by mast cells and basophils. Nature 1993;365: 340-343.

-31 Yanagihara Y, Kajiwara K, Basaki Y, Ikizawa K, Ebisawa M, Ra C, Tachimoto H, Saito H: Cultured basophils but not cultured mast cells induce human IgE synthesis in B cells after immunologic stimulation. Clin Exp Immunol 1998;111:136-143.

-32 Metz M, Grimbaldeston MA, Nakae S, Piliponsky AM, Tsai M, Galli SJ: Mast cells in promotion and limitation of chronic inflammation. Immunol Rev 2007;217:304-328.

33 Gilfillan AM, Tkaczyk C: Integrated signalling pathways for mast cell activation. Nat Rev Immunol 2006;6:218-230.

-34 Echtenacher B, Männel DN, Hueltner L: Critical protective role of mast cells in a model of acute septic peritonitis. Nature 1996;381:75-77.

-35 Malaviya R, Ikeda T, Ross E, Abraham SN: Mast cell modulation of neutrophil influx and bacterial clearance at sites of infection through TNF- $\alpha$. Nature 1996;381:77-80.

36 Piliponski AM, Chen CC, Nishimura T, Metz M, Rios EJ, Dobner PR, Wada E, Wada K, Zacharias S, Mohanasundaram UM, Faix JD, Abrink M, Pejler G, Pearl RG, Tsai M, Galli SJ: Neurotensin increases mortality and mast cells reduce neurotensin levels in a mouse model of sepsis. Nat Med 2008;14: 392-398. 
37 Benoist C, Mathis D: Mast cells in autoimmune disease. Nature 2002;420:875-878.

-38 de Paulis A, Prevete N, Fiorentino I, Walls AF, Curto M, Petraroli A, Castaldo V, Ceppa P, Fiocca R, Marone G: Basophils infiltrate human gastric mucosa at sites of Helicobacter pylori infection, and exhibit chemotaxis in response to $H$. pylori-derived peptide Hp(2-20). J Immunol 2004;172:7734-7743.

>39 Galli SJ, Tsai M, Piliponsky AM: The development of allergic inflammation. Nature 2008;454:445-454.

-40 Spitzauer S, Huss-Marp J, Brockow K, Darsow U, Behrendt H, Ring J, Kricek F, Valent P, Valenta R: Mast cell-derived proteases control allergic inflammation through cleavage of IgE. J Allergy Clin Immunol 2008;121: 197-202.

41 Estelle F, Simons R: Anaphylaxis. J Allergy Clin Immunol 2008;121(suppl):402s-407s.

42 Marshall JS, McCurdy JD, Olynych T: Tolllike receptor-mediated activation of mast cells: implications for allergic diseases? Int Arch Allergy Immunol 2003;132:87-97.

43 Vines CM, Prossnitz ER: Mechanisms of G protein-coupled receptor-mediated degranulation. FEMS Microbiol Lett 2004;236:1-6.

-44 Schroeder JT, MacGlashan DW Jr, Lichtenstein LM: Human basophils: mediator release and cytokine production. Adv Immunol 2001;77:93-122.

$\checkmark 45$ Min B, Paul WE: Basophils and type 2 immunity. Curr Opin Hematol 2008;15:59-63.

46 Voehringer D, Shinkai K, Locksley RM: Type 2 immunity reflects orchestrated recruitment of cells committed to IL-4 production. Immunity 2004;20:267-277.

$\checkmark 47$ Holgate ST: Airway inflammation and remodeling in asthma: current concepts. Mol Biotechnol 2002;22:179-189.

48 Mukai K, Matsuoka K, Taya C, Suzuki H, Yokozeki H, Nishioka K, Hirokawa K, Etori M, Yamashita M, Kubota T, Minegishi Y, Yonekawa $\mathrm{H}$, Karasuyama $\mathrm{H}$ : Basophils play a critical role in the development of IgE-mediated chronic allergic inflammation independently of $\mathrm{T}$ cells and mast cells. Immunity 2005;23:191-202.

-49 Marone G, Triggiani M, Genovese A, de Paulis AD: Role of human mast cells and basophils in bronchial asthma. Adv Immunol 2005;88:97-160.

50 Theoharides TC, Kempuraj D, Tagen M, Conti P, Kalogeromitros D: Differential release of mast cell mediators and the pathogenesis of inflammation. Immunol Rev 2007; 217:65-78.

-51 Cao J, Papadopoulou N, Kempuraj D, Boucher WS, Sugimoto K, Cetrulo CL, Theoharides TC: Human mast cells express corticotropin-releasing hormone $(\mathrm{CRH})$ receptors and $\mathrm{CRH}$ leads to selective secretion of vascular endothelial growth factor. J Immunol 2005; 174:7665-7675.
52 Puxeddu I, Ribatti D, Crivellato E, LeviSchaffer F: Mast cells and eosinophils: a novel link between inflammation and angiogenesis in allergic diseases. J Allergy Clin Immunol 2005;116:531-536.

53 Koshino T, Arai Y, Miyamoto Y, Sano Y, Itami M, Teshima S, Hirai K, Takaishi T, Ito K, Morita Y: Airway basophil and mast cell density in patients with bronchial asthma: relationship to bronchial hyperresponsiveness. J Asthma 1996;33:89-95.

54 Irani AM, Huang C, Xia HZ, Kepley C, Nafie A, Fouda ED, Craig S, Zweiman B, Schwartz LB: Immunohistochemical detection of human basophils in late-phase skin reactions. J Allergy Clin Immunol 1998;101:354-362.

55 Macfarlane AJ, Kon OM, Smith SJ, Zeibecoglou K, Khan LN, Barata LT, McEuen AR, Buckley MG, Walls AF, Meng Q, Humbert M, Barnes NC, Robinson DS, Ying S, Kay AB: Basophils, eosinophils, and mast cells in atopic and nonatopic asthma and in latephase allergic reactions in the lung and skin. J Allergy Clin Immunol 2000;105:99-107.

56 Obata K, Mukai K, Tsujimura Y, Ishiwata K, Kawano Y, Minegishi Y, Watanabe N, Karasuyama $\mathrm{H}$ : Basophils are essential initiators of a novel type of chronic allergic inflammation. Blood 2007;110:913-920.

57 Risau W: Mechanisms of angiogenesis. Nature 1997;386:671-674.

58 Dunnill MS: The pathology of asthma, with special reference to changes in the bronchial mucosa. J Clin Pathol 1960;13:27-33.

59 Li X, Wilson JM: Increased vascularity of the bronchial mucosa in mild asthma. Am J Respir Crit Care Med 1997;156:229-233.

60 Orsida BE, Li X, Hickey B, Thien F, Wilson JW, Walters EH: Vascularity in asthmatic airways: relation to inhaled steroid dose. Thorax 1999;54:289-295.

61 McDonald DM: Angiogenesis and remodeling of airway vasculature in chronic inflammation. Am J Respir Crit Care Med 2001;164: S39-S45.

62 Wilson J: The bronchial microcirculation in asthma. Clin Exp Allergy 2000;30:51-53.

63 Romagnani P, Lasagni L, Annunziato F, Serio $\mathrm{M}$, Romagnani S: CXC chemokines: the regulatory link between inflammation and angiogenesis. Trends Immunol 2004;25: 201-209.

64 Mehrad B, Keane MP, Strieter RM: Chemokines as mediators of angiogenesis. Thromb Haemost 2007;97:755-762.

65 Zaja-Milatovic S, Richmond A: CXC chemokines and their receptors: a case for a significant biological role in cutaneous wound healing. Histol Histopathol 2008;23:1399_ 1407.

66 Keeley EC, Mehrad B, Strieter RM: Chemokines as mediators of neovascularization. Arterioscler Thromb Vasc Biol 2008;28: 1928-1936.
67 Salcedo R, Oppenheim JJ: Role of chemokines in angiogenesis: CXCL12/SDF-1 and CXCR4 interactions, a key regulator of endothelial cell responses. Microcirculation 2003; 10:359-370

68 Min B, Le Gros G, Paul WE: Basophils: a potential liaison between innate and adaptive immunity. Allergol Int 2006;55:99-104.

69 Brightling CE, Kaur D, Berger P, Morgan AJ, Wardlaw AJ, Bradding P: Differential expression of CCR3 and CXCR3 by human lung and bone marrow-derived mast cells: implications for tissue mast cell migration. J Leukoc Biol 2005;77:759-766.

70 Watanabe M, Satoh T, Yamamoto Y, Kanai Y, Karasuyama H, Yokozeki H: Overproduction of IgE induces macrophage-derived chemokine (CCL22) secretion from basophils. J Immunol 2008;181:5653-5659.

71 Dvorak AM: Mast cell-derived mediators of enhanced microvascular permeability, vascular permeability factor/vascular endothelial growth factor, histamine, and serotonin, cause leakage of macromolecules through a new endothelial cell permeability organelle, the vesiculo-vacuolar organelle. Chem Immunol Allergy 2005;85:185-204.

72 de Paulis A, Prevete N, Rossi FW, Staibano S, Montuori N, Ragno P, Longobardi A, Liccardo B, Genovese A, Ribatti D, Walls AF, Marone $\mathrm{G}$ : Expression and functions of vascular endothelial growth factors and their receptors in human basophils. J Immunol 2006; 177:7322-7331.

73 Textor B, Licht AH, Tuckermann JP, Jessberger R, Razin E, Angel P, Schorpp-Kistner $\mathrm{M}$, Hartenstein B: JunB required for IgE-mediated degranulation and cytochine release of mast cells. J Immunol 2007; 179:68736880.

74 Abdel-Majid RM, Marshall JS: Prostaglandin E2 induces degranulation-independent production of vascular endothelial growth factor by human mast cells. J Immunol 2004; 172:1227-1236.

75 Cao L, Curtis CL, Theoharides TC: Corticotropin-releasing hormone induces vascular endothelial growth factor release from human mast cells via the cAMP/protein kinase A/p38 mitogen-activated protein kinase pathway. Mol Pharmacol 2006;69:998-1006.

76 Norrby K: Mast cells and angiogenesis. APMIS 2002;110:355-371.

77 Ribatti D, Belloni AS, Nico B, Sala G, Longo V, Mangieri D, Crivellato E, Nussdorfer GG: Tryptase- and leptin-positive mast cells correlate with vascular density in uterine leiomyomas. Am J Obstet Gynecol 2007;196: 470-477.

78 Kanbe N, Tanaka A, Kanbe M, Itakura A, Kurosawa M, Matsuda H: Human mast cells produce matrix metalloproteinase 9. Eur J Immunol 1999;29:2645-2649.

79 Marone G, Triggiani M, de Paulis A: Mast cells and basophils: friends as well as foes in bronchial asthma? Trends Immunol 2005; 26:25-31. 
80 Pettipher R, Hansel TT: Antagonists of the prostaglandin D2 receptor CRTH2. Drug News Perspect 2008;21:317-322.

-81 Hofstra CL, Desai PJ, Thurmond RL, FungLeung WP: Histamine $\mathrm{H} 4$ receptor mediates chemotaxis and calcium mobilization of mast cells. J Pharmacol Exp Ther 2003;305: 1212-1221.

\$2 Lippert U, Moeller A, Welker P, Artuc M, Henz BM: Inhibition of cytokine secretion from human leukemic mast cells and basophils by H1- and H2-receptor antagonists. Exp Dermatol 2000;9:118-124.

-83 Mellor EA, Maekawa A, Austen KF, Boyce JA: Cysteinyl leukotriene receptor 1 is also a pyrimidinergic receptor and is expressed by human mast cells. Proc Natl Acad Sci USA 2001;98:7964-7969.
84 Gauvreau GM, Plitt JR, Baatjes A, MacGlashan DW: Expression of functional cysteinyl leukotriene receptors by human basophils. J Allergy Clin Immunol 2005;116: 80-87.

85 Rose CE Jr, Sung SS, Fu SM: Significant involvement of CCL2 (MAP-1) in inflammatory disorders of the lung. Microcirculation 2003; 10:273-288.

86 Fureder W, Agis H, Sperr WR, Lechner K, Valent P: The surface membrane antigen phenotype of human blood basophils. Allergy 1994;49:861-865.
87 Sillaber C, Baghestanian M, Hofbauer R, Virgolini I, Bankl HC, Füreder W, Agis H, Willheim M, Leimer M, Scheiner O, Binder BR, Kiener HP, Bevec D, Fritsch G, Majdic O, Kress HG, Gadner H, Lechner K, Valent P: Molecular and functional characterization of the urokinase receptor on human mast cells. J Biol Chem 1997;272:7824-7832.

88 de Paulis A, Montuori N, Prevete N, Fiorentino I, Rossi FW, Visconte V, Rossi G, Marone G, Ragno P: Urokinase induces basophil chemotaxis through a urokinase receptor epitope that is an endogenous ligand for formyl peptide receptor-like 1 and -like 2. J Immunol 2004;173:7734-7743.

89 Carmeliet P: Angiogenesis in health and disease. Nat Med 2003;9:653-660. 